\title{
Calendar anomalies: Review of literature
}

\author{
Hira Irshad ${ }^{1}$, Hasniza Mohd Taib ${ }^{2}$ \\ 1,2 School of Economics Finance and Banking, Universiti Utara, Changlun, Malaysia
}

\section{Keywords}

Efficient market hypothesis January anomaly

Monday anomaly

Islamic calendar months effect

Received: 10 October 2017

Accepted: 6 November 2017

Published: 4 December 2017

\begin{abstract}
The objective of the current study is to review the prior studies regarding calendar anomalies. For this purpose, the current study has adopted the review methodology and identified the most important studies in this area. Furthermore, the findings of these studies have been reviewed and summarized. By reviewing the previous studies, the current study has noted the growing inclination of recent studies to examine these anomalies. Also, the prevalence of these anomalies is documented in recent studies. The current study is among the first of those studies which have provided a comprehensive review of the previous studies conducted on the calendar anomalies. These summarized reviews of previous research findings may help future research studies hold a basic understanding of the existence of calendar anomalies in the world equity markets.
\end{abstract}

(C) 2017 The Author(s). Published by TAF Publishing.

\section{INTRODUCTION \\ Background of the Study}

The concept of market efficiency indicates that share prices are adjusted in response to the relevant available information. The concept of market efficiency is divided into three hypotheses such as weak, semi strong and strong form of efficient market hypotheses. The weak form of the efficient market hypothesis specifies that share prices are accustomed to the historical share prices data. The second sub hypothesis is semi-strong form of the efficient market hypothesis which specifies that share prices are accustomed to the existing public information which may include the company's specific information and the macro indicators which may relate to stock prices. The strong form of the efficient market hypothesis specifies that share prices are accustomed to all the existing information such as historical prices information, public information and inside information.

Many studies have examined the existence of weak form of EMH in the past (Chakraborty, 2006; Guidi et al., 2011; Irshad and Sarwar, 2012; Mobarek and Fiorante, 2014; Nawaz et al., 2013; Omar et al., 2013; Ryaly et al., 2017). However, the findings of these studies were mixed. The semi strong form of EMH has been tested and mixed findings were reported (Ali et al., 2001; Hussin et al., 2010; Hsu and Utami, 2016; Khan and Ikram, 2010). Likewise, previous research has tested the strong form of efficient market hypothesis (Finnerty, 1976; Rozeff and Zaman, 1988). However, later studies have indicated many anomalous evidences regarding the efficient market hypothesis. Market anomaly refers

\footnotetext{
${ }^{*}$ Corresponding author: Hira Irshad

${ }^{\dagger}$ Email: hiraharoon48@gmail.com
} 
when investors can generate abnormal returns having market knowledge superior to others (Al-Hajieh et al., 2011; Białkowski et al., 2013; Cao and Wei, 2005; Kinata, 2016; Stulz and Williamson, 2003).

One of the most discussed areas regarding anomalies is the calendar anomalies (AlIssiss, 2015; Easterday and Sen, 2016; Jebran and Chen, 2017). Research studies have documented many anomalous evidences regarding the stock market efficiency such as January effect (Seyhun, 1993), day of the week effect (Wingender and Groff, 1989), Monday effect (Cho et al., 2007; Jaffe and Westerfield, 1985b), and wandering weekend effect (Doyle and Chen, 2009). Recently, studies have found the irrational behaviour of security prices during the Islamic calendar months such as Ramadan effect (Białkowski et al., 2012). There are very few studies which have provided a comprehensive review of previous studies regarding the Calendar anomalies. Therefore, the current study has provided a review of relevant previous studies. Thus, the purpose of current study is to identify and review the most significant studies relating to the calendar anomalies.

\section{RESEARCH METHODOLOGY}

Regarding the methodology of the current study, the current study has reviewed the most significant studies relating to the calendar anomalies. Also, the current study has reviewed the previous studies relating to the Islamic calendar months and summarized the findings of those studies. Based on the review, the current study highlights the directions for future research regarding the calendar anomalies relating to the efficient market hypothesis.

\section{REVIEW OF LITERATURE}

The research studies have documented numerous evidences of abnormal share prices behaviour during certain calendar dates which are known as calendar anomalies (Majeed et al., 2015). The existence of this anomalous evidence casts doubt on the efficiency of equity markets. The purpose of the current study is to review the findings of previous studies conducted on the calendar anomalies. More specifically, the current study has mainly focused on three types of calendar anomalies, January effect, Monday effect and Islamic calendar months' anomalies. The review of previous studies has been presented in the following sections.

\section{January Effect}

The January effect indicates the abnormal behaviour of stock prices in January which is termed as January anomaly. The share prices tend to remain higher during the month of January in comparison to the other eleven months (Beladi et al., 2016). Previous studies have highlighted different possible explanations to this anomalous stock market behaviour. For instance, Lakonishok and Smidt (1988) state that shares are sold in the month of December by the fund managers because of the tax reasons. It reduces the stock prices in the month of December and indicates negative equity returns. These stocks are repurchased in the month of January therefore the stock prices are increased in the month of January. The liquidity of investors is higher in the month of January which increases the trading volume and increases the stock prices in the month of January (Ligon, 1997).

Aggarwal and Rivoli (1989) examined calendar anomalies for the Hong Kong, Singapore, Philippines and Malaysia stock markets. They found that Philippines market is efficient and no one can gain the abnormal return in January since the January anomaly does not persist in Philippines stock market whereas in case of Hong Kong, Singapore, and Malaysia there is reverse state of affairs. The findings state that January anomaly exist and stock markets are not efficient in terms of January effect. Likewise, Gu (2003) analysed the USA market behaviour regarding the January anomaly. Their findings were in line with the 
January anomaly in that it confirms the presence of January effect. Similarly, many others have provided the evidence on the existence of January effect (Beladi et al., 2016; Moller and Zilca, 2008; Norvaisiene et al., 2015). On contrary, findings of other studies support the efficient market hypothesis and do not find the existence of January effect (Diaconasu et al., 2012; Jebran and Chen, 2017; Seif et al., 2017). Following Table provides some important studies conducted on the existence of January effect.

TABLE 1. January effect

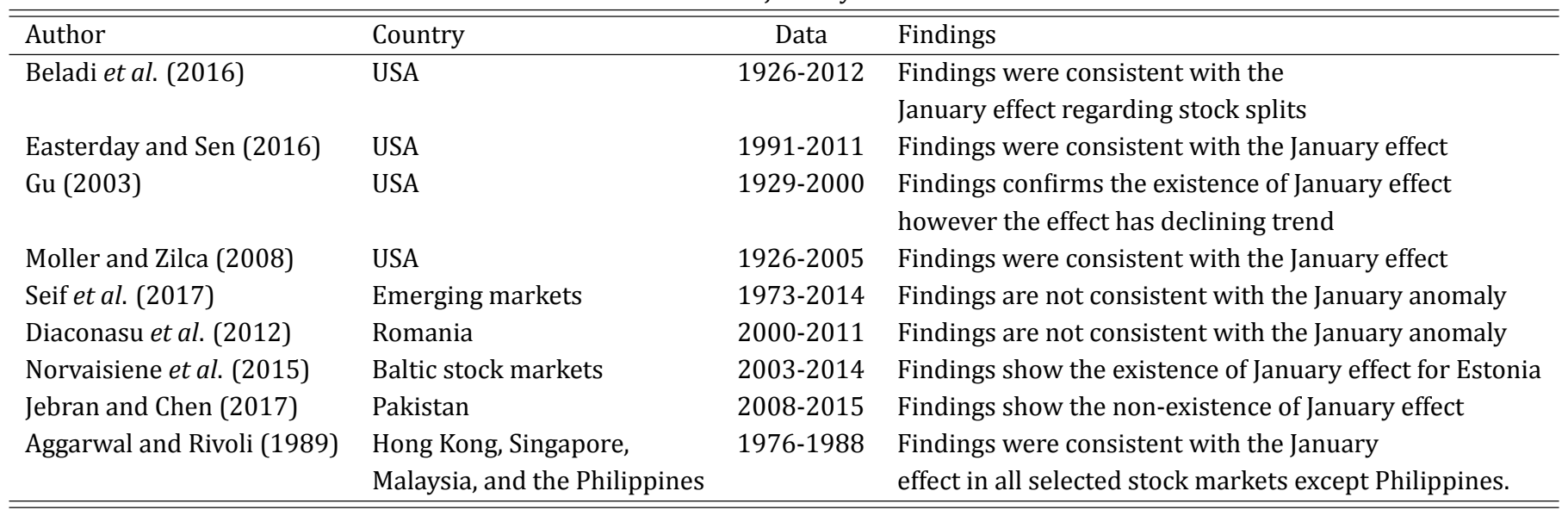

\section{Monday Effect}

The Monday effect is one of most documented anomalies in the previous studies. The Monday effect states that stock returns are significantly negative on Monday. Since, the stock prices are lower on Monday it provides a predictable pattern to the investors which violates the assumption of market efficiency. The Monday effect was reported by Gibbons and Hess (1981) providing evidence of low returns on Monday. Furthermore, it was observed that returns are higher on Friday. Monday as a day of strategy formulation for the rest of week is one possible explanation to this anomaly as postulated by previous research (Lakonishok and Maberly, 1990; Ritter, 1988). However, other studies have given different explanations to this effect such as announcement of negative news on Friday by the firms results in negative returns on coming Monday (Damodaran, 1989).

Findings of previous studies are mixed regarding the Monday effect. The findings of many studies were consistent with the Monday effect and others have provided the support to the market efficiency instead of the Monday effect. There are number of studies which have supported the Monday effect in the stock markets (Alt et al., 2011; Cho et al., 2007; Jaffe et al., 1989). However, other studies support the efficient market hypothesis and are not in line with the Monday effect (Bhana, 1985; Diaconasu et al., 2012; Mehdian and Perry, 2001; Wang et al., 1997). Also, Ajayi et al. (2004) examined the Monday effect in Eastern European countries and reported that Monday effect is consistent in six countries whereas inconsistent in the rest of five countries. Following table provides some important studies conducted on the existence of Monday effects. 
TABLE 2 . Monday/weekend/day of the week effect

\begin{tabular}{|c|c|c|c|}
\hline Author & Country & Data & Findings \\
\hline Diaconasu et al. (2012) & Romania & $2000-2011$ & $\begin{array}{l}\text { Findings are not consistent } \\
\text { with the Monday effect }\end{array}$ \\
\hline Wang et al. (1997) & USA & $1962-1993$ & $\begin{array}{l}\text { Findings are not consistent } \\
\text { with the Monday effect }\end{array}$ \\
\hline Cho et al. (2007) & USA, UK, Japan & $1970-2004$ & $\begin{array}{l}\text { Findings are consistent } \\
\text { with Monday effect }\end{array}$ \\
\hline Aggarwal and Rivoli (1989) & $\begin{array}{l}\text { Hong Kong, Singapore, } \\
\text { Malaysia, and the Philippines }\end{array}$ & 1976-1988 & All markets exhibit weekend effect \\
\hline Alt et al. (2011) & US, UK and Germany & $1970-2008$ & Findings support the Monday effect \\
\hline Draper and Paudyal (2002) & UK & 1988-1997 & $\begin{array}{l}\text { Results reveal a significant } \\
\text { day-of-the-week effect }\end{array}$ \\
\hline Jaffe et al. (1989) & $\begin{array}{l}\text { USA, Canada, Australia, } \\
\text { England and Japan }\end{array}$ & $1930-1981$ & $\begin{array}{l}\text { Findings are consistent } \\
\text { with the Monday effect }\end{array}$ \\
\hline Mehdian and Perry (2001) & USA & 1964-1998 & $\begin{array}{l}\text { Findings are not consistent } \\
\text { with the Monday effect }\end{array}$ \\
\hline Ajayi et al. (2004) & Eastern European countries & From inception of index-2002 & $\begin{array}{l}\text { Findings are consistent with the } \\
\text { Monday effect in six countries whereas } \\
\text { inconsistent in the rest of five countries }\end{array}$ \\
\hline
\end{tabular}

\section{Islamic Calendar Anomalies}

The Islamic calendar anomalies indicate the abnormal behaviour of equity markets during the Islamic calendar months. Previous studies have reported the positive investor behaviour during the month of Ramadan indicating the positive abnormal returns whereas negative behaviour during the month of Muharram indicating the negative returns during the month of Muharram (Al-Ississ, 2010; Halari et al., 2015). There are different seasonal patterns of stock returns documented based on the Islamic calendar. One of the most widely examined pattern is the Ramadan effect. The month of the Ramadan is considered the holy month in the Islamic calendar. Studies have documented the positive stock returns during the month of Ramadan (Al-Ississ, 2010; Al-Khazali et al., 2017) whereas negative returns are documented during the month of Muharram (Al-Ississ, 2010).

Furthermore, Halari et al. (2015) documented the existence of Islamic calendar anomalies in stock market of Pakistan. Likewise, Seyyed et al. (2005) found the existence of Ramadan effect in Saudi Arabia. Also, Białkowski et al. (2013) found that mutual fund managers earn positive returns during the month of Ramadan. On contrary, findings of some studies do not support the Islamic calendar anomalies and are in line with the market efficiency concept. For instance, Shah et al. (2017) examined the behaviours of stock markets during the Islamic months. The effects of Ramadhan and Zil-Haj on the global equity indices were explored and no significant effects were testified. Likewise, Syed and Khan (2017) examined the Islamic calendar months and stated that their study does not support the Islamic calendar months anomaly. Following table provides some important studies conducted on the existence of Islamic calendar effect. 
TABLE 3 . Monday/weekend/day of the week effect

\begin{tabular}{|c|c|c|c|}
\hline Author & Country & Data & Findings \\
\hline Halari et al. (2015) & Pakistan & 1996-2011 & $\begin{array}{l}\text { Consistent with the } \\
\text { Islamic calendar months effects }\end{array}$ \\
\hline Shah et al. (2017) & Global Islamic indices & 2011-2015 & $\begin{array}{l}\text { Not consistent with the } \\
\text { Islamic calendar months effect }\end{array}$ \\
\hline Seyyed et al. (2005) & Saudi Arabia & $1985-2000$ & Confirms the Ramadan effect \\
\hline Husain (1998) & Pakistan & $1989-1993$ & $\begin{array}{l}\text { Confirms the Ramadan effect and } \\
\text { volatility decreases in the returns } \\
\text { during the month of Ramadan }\end{array}$ \\
\hline Białkowski et al. (2012) & 14 muslim countries & 1989-2007 & Confirms the Ramadan effect \\
\hline Al-Ississ (2010) & 17 Financial markets & $1988-2009$ & $\begin{array}{l}\text { Consistent with the } \\
\text { Islamic calendar months effects }\end{array}$ \\
\hline Almudhaf (2012) & $\begin{array}{l}12 \text { countries with } \\
\text { majority of Muslims }\end{array}$ & & $\begin{array}{l}\text { Consistent with the Islamic } \\
\text { calendar months effects }\end{array}$ \\
\hline Białkowski et al. (2013) & Turkey & $2000-2011$ & $\begin{array}{l}\text { Performance of mutual funds is } \\
\text { higher during the month of Ramadan }\end{array}$ \\
\hline Gavriilidis et al. (2015) & Seven muslim countries & 1990-2014 & $\begin{array}{l}\text { Herding behaviour observed } \\
\text { during the month of Ramadan }\end{array}$ \\
\hline Al-Khazali et al. (2017) & 15 Islamic countries & $2005-2015$ & $\begin{array}{l}\text { Stock return volatility decreases } \\
\text { during the month of Ramadan in } \\
\text { line with the Ramadan effect }\end{array}$ \\
\hline Wasiuzzaman and Al-Musehel (2017) & Saudi Arabia and Iran & $2008-2014$ & $\begin{array}{l}\text { Significant impact of Ramadan } \\
\text { on Stock returns in Saudi Arabia and } \\
\text { insignificant impact on the } \\
\text { stock returns in Iran }\end{array}$ \\
\hline Al-Hajieh et al. (2011) & Islamic middle eastern countries & 1992-2007 & $\begin{array}{l}\text { Ramadan effect is } \\
\text { significant in most of the } \\
\text { Middle Eastern Countries }\end{array}$ \\
\hline Iqbal et al. (2013) & Pakistan & 1992-2011 & Significant Islamic month effect \\
\hline
\end{tabular}

\section{CONCLUSION}

The purpose of the current study is to highlight the anomalous evidence regarding the efficient market hypothesis by reviewing the previous research studies. It has been observed that findings of most of the previous studies are in line with the calendar effects and cast doubt on the concept of market efficiency. The current research has significant implications for stockholders and portfolio managers in the stock markets. It provides the review of all the most important previous studies on this subject. Previous studies indicate that investors are influenced by the emotions and sentiments therefore their investment decisions are directed by their moods resulting in irrational investing. Besides, the evidence on existence of other calendar anomalies such as month of the year effect (Norvaisiene et al., 2015; Seif et al., 2017), holiday (Seif et al., 2017), holy day effect (Al-Ississ, 2015; Ali et al., 2017; Frieder and Subrahmanyam, 2004; Oğuzsoy and Güven, 2004) is also documented in previous research.

\section{LIMITATIONS DN RECOMMENDATIONS}

However, the current study has reviewed three most central types of calendar effects and future review studies may include other calendar anomalies along with January, Monday and Islamic Calendar anomalies. 


\section{REFERENCES}

Aggarwal, Reena, and Pietra Rivoli. 1989. Seasonal and day-of-the-week effects in four emerging stock markets. Financial Review 24, no. 4: 541-550. D0I: 10.1111/j.1540-6288.1989.tb00359.x

Ajayi, Richard A., Seyed Mehdian, and Mark J. Perry. 2004. The day-of-the-week effect in stock returns: Further evidence from Eastern European emerging markets. Emerging Markets Finance and Trade 40, no. 4: 53-62.

Al-Hajieh, Heitham, Keith Redhead, and Timothy Rodgers. 2011. Investor sentiment and calendar anomaly effects: A case study of the impact of Ramadan on Islamic Middle Eastern markets. Research in International Business and Finance 25, no. 3: 345-356. DOI: 10.1016/j.ribaf.2011.03.004

Ali, Irfan, Waheed Akhter, and Namrah Ashraf. 2017. Impact of muslim holy days on Asian stock markets: An empirical evidence. Cogent Economics \& Finance 5, no. 1 (2017): 2-10. DOI: 10.1080/23322039.2017.1311096

Ali, Salman Syed, Khalid Mustafa, and Asad Zaman. 2001. Testing semi-strong form efficiency of stock market. The Pakistan Development Review 40, no. 4: 651-674.

Al-Ississ, Mohamad. 2010. The impact of religious experience on financial markets. Working paper no 79, Harvard Kennedy School of Government, Harvard University, Cambridge, MA.

Al-Ississ, Mohamad. 2015. The holy day effect. Journal of Behavioral and Experimental Finance 5: 60-80. DOI: $10.1016 /$ j.jbef.2015.02.007

Al-Khazali, Osamah, Elie Bouri, David Roubaud, and Taisier Zoubi. 2017. The impact of religious practice on stock returns and volatility. International Review of Financial Analysis 52: 172-189. D0I: 10.1016/j.irfa.2017.04.009

Almudhaf, Fahad. 2012. The Islamic calendar effects: Evidence from twelve stock markets.

URL: goo.gl/vC99yR (accessed on August 18, 2012)

Alt, Raimund, Ines Fortin, and Simon Weinberger. 2011. The Monday effect revisited: An alternative testing approach.

Jour- nal of Empirical Finance 18, no. 3: 447-460. DOI: 10.1016/j.jempfin.2011.04.002

Beladi, Hamid, Chi Chur Chao, and May Hu. 2016. Another January effect evidence from stock split announcements. In- $\quad$ ternational Review of Financial Analysis 44: 123-138. DOI: 10.1016/j.irfa.2016.01.007

Bhana, N. 1985. The Monday effect on the Johannesburg Stock Exchange. South African Journal of Business Management 16, no. 1: 7-11.

Białkowski, Jędrzej, Ahmad Etebari, and Tomasz Piotr Wisniewski. 2012. Fast profits: Investor sentiment and stock returns during Ramadan. Journal of Banking \& Finance 36, no. 3: 835-845. DOI: 10.1016/j.jbankfin.2011.09.014

Białkowski, Jędrzej, Martin T. Bohl, Philipp Kaufmann, and Tomasz P. Wisniewski. 2013. Do mutual fund managers exploit the Ramadan anomaly? Evidence from Turkey. Emerging Markets Review 15: 211-232.

DOI: 10.1016/j.ememar.2013.02.003

Cao, Melanie, and Jason Wei. 2005. Stock market returns: A note on temperature anomaly. Journal of Banking \& Finance 29, no. 6: 1559-1573. DOI: 10.1016/j.jbankfin.2004.06.028

Chakraborty, Madhumita. 2006. Market efficiency for the Pakistan stock market: Evidence from the Karachi stock exchange. South Asia Economic Journal 7, no. 1: 67-81. D0I: 10.1177/139156140500700104

Cho, Young-Hyun, Oliver Linton, and Yoon-Jae Whang. 2007. Are there Monday effects in stock returns: A stochastic domi- nance approach. Journal of Empirical Finance 14, no. 5: 736-755. DOI: 10.1016/j.jempfin.2007.02.001

Damodaran, Aswath. 1989. The weekend effect in information releases: A study of earnings and dividend announcements.

The Review of Financial Studies 2, no. 4: 607-623. D0I: 10.1093/rfs/2.4.607

Diaconasu, Delia-Elena, Seyed Mehdian, and Ovidiu Stoica. 2012. An examination of the calendar anomalies in the Romanian stock market. Procedia Economics and Finance 3: 817-822. DOI: 10.1016/s2212-5671(12)00235-3

Doyle, John R., and Catherine Huirong Chen. 2009. The wandering weekday effect in major stock markets. Journal of Bank- $\quad$ ing \& Finance 33, no. 8: 1388-1399. D0I: 10.1016/j.jbankfin.2009.02.002

Draper, Paul, and Krishna Paudyal. 2002. Explaining monday returns. Journal of Financial Research 25, no. 4: 507-520. DOI: $10.1111 / 1475-6803.00034$ 
Easterday, Kathryn E., and Pradyot K. Sen. 2016. Is the January effect rational? Insights from the accounting valuation model. The Quarterly Review of Economics and Finance 59: 168-185. D0I: 10.1016/j.qref.2015.05.001

Finnerty, Joseph E. 1976. Insiders and market efficiency. The Journal of Finance 31, no. 4: 1141-1148.

DOI: $10.1111 / j .1540-6261.1976 . t b 01965 . x$

Frieder, Laura, and Avanidhar Subrahmanyam. 2004. Nonsecular regularities in returns and volume. Financial Analysts

Journal 60, no. 4: 29-34. DOI: 10.2469/faj.v60.n4.2634

Gavriilidis, Konstantinos, Vasileios Kallinterakis, and Ioannis Tsalavoutas. 2015. Investor mood, herding and the Ramadan effect. Journal of Economic Behavior \& Organization 132: 23-38. DOI: 10.1016/j.jebo.2015.09.018

Gibbons, Michael R., and Patrick Hess. 1981. Day of the week effects and asset returns. Journal of Business 54, no. 4: 579- 596. DOI: $10.1086 / 296147$

$\mathrm{Gu}$, Anthony Yanxiang. 2003. The declining January effect: Evidences from the US equity markets. The Quarterly Review of Economics and Finance 43, no. 2: 395-404. DOI: 10.1016/s1062-9769(02)00160-6

Guidi, Francesco, Rakesh Gupta, and Suneel Maheshwari. 2011. Weak-form market efficiency and calendar anomalies for eastern Europe equity markets. Journal of Emerging Market Finance 10, no. 3: 337-389.

DOI: $10.1177 / 097265271101000304$

Halari, Anwar, Nongnuch Tantisantiwong, David M. Power, and Christine Helliar. 2015. Islamic calendar anomalies: Evi- dence from Pakistani firm-level data. The Quarterly Review of Economics and Finance 58: 64-73.

DOI: $10.1016 /$ j.qref.2015.02.004

Hsu, Ai-Chi, and Fiesty Utami. 2016. Central bank intervention and stock market response. International Journal of Busi- $\quad$ ness and Administrative Studies 2, no. 5: 151-161. D0I: 10.20469/ijbas.2.10005-5

Husain, Fazal. 1998. A seasonality in the Pakistani equity market: The Ramadhan effect. The Pakistan Development Re- $\quad$ view 37, no. 1: 77-81.

Hussin, Baharuddin M., Abdullahi D. Ahmed, and Teoh C. Ying. 2010. Semi-strong form efficiency: Market reaction to divi- dend and earnings announcements in Malaysian stock exchange. IUP Journal of Applied Finance 16, no. 5: 36-60. Iqbal, Muhammad Shahid, Rehana Kouser, and Muhammad Azeem. 2013. Conventional and islamic anomalies in Karachi stock exchange. Science International 25, no. 4: 999-1007.

Irshad, Hira, and Ghulam Sarwar. 2012. Is Karachi stock market weak form efficient? The Journal of Commerce, 5, no. 1: 7-13.

Jaffe, Jeffrey F., Randolph Westerfield, and Christopher Ma. 1989. A twist on the Monday effect in stock prices: Evidence from the US and foreign stock markets. Journal of Banking \& Finance 13, no. 4-5: 641-650.

DOI: $10.1016 / 0378-4266(89) 90035-6$

Jaffe, Jeffrey, and Randolph Westerfield. 1985a. Patterns in Japanese common stock returns: Day of the week and turn of the year effects. Journal of Financial and Quantitative Analysis 20, no. 2: 261-272. D0I: 10.2307/2330959

Jaffe, Jeffrey, and Randolph Westerfield. 1985b. The week-end effect in common stock returns: The international evidence.

The Journal of Finance 40, no. 2: 433-454. DOI: 10.1111/j.1540-6261.1985.tb04966.x

Jebran, Khalil, and Shihua Chen. 2017. Examining anomalies in Islamic equity market of Pakistan. Journal of Sustainable

Finance \& Investment 7, no. 3: 275-289. DOI: 10.1080/20430795.2017.1289455

Khan, A. Q., and Sana Ikram. 2010. Testing semi-strong form of efficient market hypothesis in relation to the impact of For- eign Institutional Investors'(FII's) investments on Indian capital market. International Journal of Trade, Economics and Finance 1, no. 4: 373-379. DOI: 10.7763/ijtef.2010.v1.66

Kinata, Edric Julio. 2016. The effect of market volatility and firm size towards the difference of market reaction around stock-split announcement in Indonesia stock exchange. Journal of Administrative and Business Studies 2, no. 6 : 304- 313. DOI: $10.20474 /$ jabs-2.6.5

Lakonishok, Josef, and Edwin Maberly. 1990. The weekend effect: Trading patterns of individual and institutional investors.

The Journal of Finance 45, no. 1: 231-243. DOI: 10.1111/j.1540-6261.1990.tb05089.x

Lakonishok, Josef, and Seymour Smidt. 1988. Are seasonal anomalies real? A ninety-year perspective. The Review of Fi- $\quad$ nancial Studies 1, no. 4: 403-425. DOI: 10.1093/rfs/1.4.403 
Ligon, James A. 1997. A simultaneous test of competing theories regarding the January effect. Journal of Financial Re- search 20, no. 1: 13-32. DOI: 10.1111/j.1475-6803.1997.tb00234.x

Majeed, Usman, Abdul Raheman, M. Khalid Sohail, Ghulam Ali Bhatti, and Bushra Zulfiqar. 2015. Islamic calendar events and stock market reaction: Evidence from Pakistan. Science International 27, no. 3: 2559-2567.

Mehdian, Seyed, and Mark J. Perry. 2001. The reversal of the Monday effect: New evidence from US equity markets. Journal of Business Finance \& Accounting 28, no. 7-8: 1043-1065. D0I: 10.1111/1468-5957.00404

Mobarek, Asma, and Angelo Fiorante. 2014. The prospects of BRIC countries: Testing weak-form market efficiency. Re- search in International Business and Finance 30: 217-232. D0I: 10.1016/j.ribaf.2013.06.004

Moller, Nicholas, and Shlomo Zilca. 2008. The evolution of the January effect. Journal of Banking \& Finance 32, no. 3: 447-457. DOI: 10.1016/j.jbankfin.2007.06.009

Nawaz, Bilal, Asma Sarfraz, Haroon Hussain, and Mohsin Altaf. 2013. An empirical investigation on the existence of weak form efficiency: The case of Karachi stock exchange. Management Science Letters 3, no. 1: 65-72.

DOI: $10.5267 /$ j.msl.2012.10.025

Norvaisiene, Rasa, Jurgita Stankeviciene, and Ausrine Lakstutiene. 2015. Seasonality in the Baltic stock markets. Procediacial and Behavioral Sciences 213: 468-473. DOI: 10.1016/j.sbspro.2015.11.435

Oğuzsoy, Cemal Berk, and Sibel Güven. 2004. Holy days effect on Istanbul stock exchange. Journal of Emerging Market Finance 3, no. 1: 63-75. DOI: 10.1177/097265270400300104

Omar, Muhammad, Haroon Hussain, Ghulam Ali Bhatti, and Mohsin Altaf. 2013. Testing of random walks in Karachi stock exchange. Elixir Financial Management 54: 12293-12299.

Ritter, Jay R. 1988. The buying and selling behavior of individual investors at the turn of the year. The Journal of Finance 43, no. 3: 701-717. DOI: 10.1111/j.1540-6261.1988.tb04601.x

Rozeff, Michael S., and Mir A. Zaman. 1988. Market efficiency and insider trading: New evidence. Journal of Business 60, no. 1: 25-44. DOI: $10.1086 / 296418$

Ryaly, Venkata Rajasekhar, GV Subba Raju, and Bhargava Urlankula. 2017. Te sting the weak-form market efficiency in the Indian stock market: Evidence from the Bombay Stock Exchange Index (BSE) sensex. Indian Journal of Finance 11, no. 3: 26-40. DOI: $10.17010 / \mathrm{ijf} / 2017 / \mathrm{v} 11 \mathrm{i} 3 / 111647$

Seif, Mostafa, Paul Docherty, and Abul Shamsuddin. 2017. Seasonal anomalies in advanced emerging stock markets. The Quarterly Review of Economics and Finance 66: 169-181. D0I: 10.1016/j.qref.2017.02.009

Seyhun, H. Nejat. 1993. Can omitted risk factors explain the January effect? A stochastic dominance approach. Journal of Financial and Quantitative Analysis 28, no. 2: 195-212. D0I: $10.2307 / 2331286$

Seyyed, Fazal J., Abraham Abraham, and Mohsen Al-Hajji. 2005. Seasonality in stock returns and volatility: The Ramadan effect. Research in International Business and Finance 19, no. 3: 374-383. D0I: 10.1016/j.ribaf.2004.12.010

Shah, Nida, Muhammad Nadeem Qureshi, and Yasra Aslam. 2017. An empirical investigation of Islamic calendar effect in global Islamic equity indices. International Journal of Economics and Finance 9, no. 6: 57-65.

DOI: $10.5539 /$ ijef.v9n6p57

Stulz, Rene M., and Rohan Williamson. 2003. Culture, openness, and finance. Journal of Financial Economics 70, no. 3: 313-349. DOI: 10.1016/s0304-405x(03)00173-9

Syed, Fatima, and Naimat U. Khan. 2017. Islamic calendar anomalies: Evidence from Pakistan. Business \& Economic Re- $\quad$ view 9, no. 3: 1-30. D0I: 10.22547/ber/9.3.4

Wang, Ko, Yuming Li, and John Erickson. 1997. A new look at the Monday effect. The Journal of Finance 52, no. 5: 2171- 2186. DOI: $10.2307 / 2329480$

Wasiuzzaman, Shaista, and Noura Abdullah Al-Musehel. 2017. Mood, religious experience and the Ramadan effect. Inter- $\quad$ national Journal of Emerging Markets 3, no. 1: 290-307. DOI: 10.1108/ijoem-01-2017-0001

Wingender, John, and James E. Groff. 1989. On stochastic dominance analysis of day-of-the-week return patterns. Journal of Financial Research 12, no. 1: 51-55. D0I: 10.1111/j.1475-6803.1989.tb00100.x 